\title{
REFLECTIONS ON JOSEPH LISTER'S EDINBURGH EXPERIMENTS ON VASO-MOTOR CONTROL
}

\author{
by
}

A. E. BEST

JOSEPH LISTER's research on the neural control of the calibre of smaller blood-vessels was informed by two important, though unrelated discoveries, which had been engaging his attention for some time before his first surgical appointment in Edinburgh. ${ }^{1}$ These were the discoveries of (1) plain muscle-fibre, which had been observed and minutely described by Albert Kölliker, and (2) syndromes in the facial parts of mammals which followed upon the section of the cervical extension of the sympathetic chain.

Kölliker's microscopic observations during the late 1840 s of the structure of plain muscular 'elements', had shown that these consisted not of 'long, uniformly wide bands, which were studded with several nuclei, but of comparatively short, separate fibres, each of which contained one nucleus' ${ }^{2}$ He described these cells-for such, of course, they were, as conforming roughly to three kinds of shapes. Some were 'short, roundish, spindle or rectangular flakes (Plättchen)'; others were 'fairly long laminae having rectangular, spindle or club-like shapes with pointed or jagged ends'; and others were 'spindle-shaped, narrow, cylindrical fibres with straight or wavy, delicately extended ends'. ${ }^{3}$

Now during some microscopic observations-probably with a Power and Lealand instrument-made whilst he was still completing his medical training at University College Hospital, London, Lister saw that the sphincter tissue of the iris had the same structure as those plain muscle-cells described by Kölliker. ${ }^{4}$ Lister's publication of the paper describing this research was mainly in defence of Kölliker against the views of Bowman and Brodhurst, who had denied the conclusions of the German physiologist respecting the nature of such tissue. ${ }^{5}$ During the next three years, Lister published papers on related topics, two of which were on involuntary muscle-fibres and on the muscular tissue of the skin, ${ }^{6}$ and another, superbly illustrated, on the cellular nature of involuntary muscle-fibre. ${ }^{7}$ Again, these papers were mainly in defence of Kölliker, the last being directed against the findings of Mazonn and Ellis.

In preparing muscular tissue for microscopic examination, Mazonn had employed

I Lister's interest in physiological topics probably sprang from his acquaintance with William Sharpey who stressed the importance of pathological surgery. There is an account of how Lister was led to his own investigations in Edinburgh in 'Third Huxley Lecture', Brit. med. J., October 1900, p. $869 b$.

A. Kölliker, 'Beiträge zur Kenntnis der glatten Muskeln', Ztschr. wiss. Zoo., 1848, $1,48$.

Ibid.

' Lister, 'Observations on the contractile tissue of the iris', Quart. J. Micros. Sci., 1853, 1, 8f.

- W. Bowman, Lectures on the Parts concerned in the Operations on the Eye, 1849, p. 49. B. E. Brodhurst, 'The human iris; its structure and physiology', Proc. R. Soc., 1851, 6, 84.

- Lister, 'The muscular tissue of the skin', Quart. J. Micros. Sci., 1853, 1, $262 \mathrm{f}$.

' Lister, Trans. R. Soc. Edin., 1857, 21, Pt. 4, $549 f$. 


\section{Reflections on Joseph Lister's Edinburgh Experiments on Vaso-motor Control}

the technique of treating it with a dilute solution of nitric acid. He described the club-like swellings which appeared at intervals along the fibres of the prepared tissue, but he could find no nuclei within them. Indeed, the swellings themselves appeared to be merely the effect of the nitric acid solution. The fibres, he claimed, were very much like the familiar ones of newly-formed connective tissue (des neugebildeten Bindegewebes). Hence he rejected Kölliker's theory that the musclefibres were separate cells which were stuck to each other lengthwise. Rod-shaped nuclei, which were essential to Kölliker's interpretation were not to be found. ${ }^{8}$ Each muscle-fibre was a continuous thread. Ellis was of the same opinion. Using a solution of acetic acid to prepare the tissue, he was able to bring the details of the fibres sufficiently into view to satisfy himself that the 'fusiform or rod-shaped' bodies seen within the muscular tissue were not, in fact, nuclei but markings in the sheaths of the fibres; in neither voluntary nor involuntary muscle were the fibres cellular. ${ }^{9}$

In the autumn of 1856, Lister had occasion to inspect the arterioles in the web of a frog's hind leg. Raising layers of skin on the plantar side of two adjacent toes, he was able to expose and to tease out the smaller arteries and their minute branchlets. ${ }^{10}$ These arterioles were highly suitable for microscopic examination. Greatly magnified, they showed their three surrounding coats, of which the middle one consisted of a single layer of 'muscular fibre-cells', each wrapped spirally round the innermost membrane. Treatment with acetic acid brought the disputed nuclei into view, that they were really nuclei being shown by the fact that they came into view as the focus of the microscope passed from the upper to the lower wall of the fibrous body. Lister explained that the variations in shape of these cells-from long tubular bodies with pointed ends and elongated nuclei to short 'spindles' with squat nuclei-was due to the different phases of contraction. He surmised that the transverse striated swellings, which were apparent in the shorter cells, were due to puckering, and he confirmed this by showing that the squat cells of a piece of contracted intestine could be so extended mechanically that under magnification they looked like 'delicate glass threads', each with an extended nucleus. ${ }^{11}$ As Lister said in retrospect long afterwards, a more efficient 'mechanism' for constricting these vessels could hardly be imagined. ${ }^{12}$

Lister elaborated on these observations in a paper entitled 'On the early Stages of Inflammation', which he read to the Royal Society shortly afterwards. He said that 'while the capillaries consist ... of a delicate homogeneous membrane ... the minute arteries, some of these even less in calibre than average capillaries, were found to possess three distinct coats, namely, an external layer of cellular tissue . . . longitudinally arranged, an internal, extremely delicate, lining membrane, and an intermediate circular coat, which constituted the principal bulk of the vascular parietes,

3. F. Mazonn, 'Untersuchungen über die Gewebeselemente der glatten Muskeln $\ldots$ ' Arch. Anat. Physiol., 1854, 25f. See p. 34: 'Die Kölliker'schen Faserzellen sind nicht isolirte und der Länge nach nur verklebte Zellen, ebensowenig enthalten sie einen stabförmigen Kern, sondern sie sind durch Präparation entstandene Bruchstücke wirklicher continuirtlicher Fasern.'

G. V. Ellis, 'Researches into the nature of involuntary muscle fibre', Proc. $R$. Soc., 1856-57, 8, 212f.

${ }^{10}$ Lister, Trans. R. Soc. Edin., 1857, 21, Pt. 4, 551.

11 Ibid., p. 553.

18 Lister, 'Third Huxley Lecture', Brit. med. J., October 1900, 873b. 


\section{A. E. Best}

and which, when highly magnified, was found to consist of a single layer of muscular fibre-cells, each wound spirally round the internal membrane so as to encircle it from one and a half to two and a half times.'18

Shortly before this, Lister had been following the researches of several French workers on the denervation of the sympathetic nerve. Experiments which involved the observation of certain effects, particularly in the eyes, after the section or ligation of the cervical branch of the sympathetic chain, had been carried out from the second decade of the eighteenth century. Some of these experiments-for instance, those of John Reid-which were carried out on the cervical sympathetic nerve of a cat, ${ }^{14}$ were hardly more refined than those of Pourfour du Petit in the early eighteenth century. During the 1840s, however, these experiments, especially those performed by Seraphino Biffi on dogs, ${ }^{15}$ were characterized by a new rigour. Thus, about 1843 , the physiologist Rüte was carrying out sections of motor nerves, sympathetic and otherwise, in order to throw light on the mechanism of the iris. ${ }^{16}$ Within a few years, the technique of nerve-section was being used, not only to study the effects of cervical sympathetic denervation, but to investigate the places of superficial origin of the nerve within the spinal canal. ${ }^{17}$ Budge and Waller carried out controlled experimentswhich gained them the Award of the Académie des Sciences for 1852-demonstrating that 'those characteristics of the cervical branch of the great sympathetic are connected with a region of the spinal medulla which lies between the seventh cervical and the second dorsal vertebrae'. ${ }^{18}$ It was now evident that the cervical sympathetic, though not of cranial origin-it was directed, on the contrary, from the neck towards the head-was nevertheless an outflow from the 'cerebro-spinal system'. Furthermore it was shown by Claude Bernard that the familiar syndromes of the eye were only some of the effects produced by the division of the appropriate part of the sympathetic chain. ${ }^{19}$ Resuming this research, Budge showed that these other effects, for instance,

20 Lister, 'On the early stages of inflammation', Phil. Trans. R. Soc., 1858 148, Pt. 2, 653.

14 Reid, 'On the effects of lesion of the trunk of the ganglionic system of nerves in the neck upon the eyeball . . . Edin. med. surg. J., August, 1839 (quoted in Reid's Physiological, Anatomical and Pathological Researches, Edinburgh, 1848, p. 291f.).

16 Biffi, 'Intorno all 'influenza che hanno sull'occhio i due nervi grande simpatico e vago' (1846), Opere Complete del S. Biffi., Milan, 1902.

16 C. G. T. Rüte, Klinische Beitrage zur Pathologie und Physiologie der Augen . . . Brunswick, 1843, p. 244f: 'Dieser Umstand spricht dafür dass die Aeste des N. Oculomotorius nur die Arkfasern der Iris versehen, und die Verengerung der Pupille vermitteln. Die Langsfasern der Iris, welche die Erweiterung der Pupille bewirken, scheinen dagegen von andern Nerven [welche vom $\mathbf{N}$. Sympathicus entspringen] ihre Contractionsfähigkeit $\mathrm{zu}$ erhalten . . . (slightly abridged)

${ }_{17}$ Budge and Waller, 'Recherches sur le systeme nerveux', $C$. $r$. hebd. Séanc. Acad. Sci., Paris, $1851,33,370 f$.

18 Budge and Waller, C. r. hebd. Séanc. Acad. Sci., Paris, 1852, 35, 895: 'Si l'on détruit cette partie de la moelle, l'influence du grand sympathique sur l'iris disparait; d'où l'on tire cette conséquence, que c'est la moelle épinière qui influence les mouvements de la pupille, et que le rôle du nerf sympathique est de transmettre cette influence, au lieu de l'exercer de luj-méme, comme il était naturel de le penser d'après les expériences qui viennent d'être citées .... Une autre conséquence qu'on pourrait encore déduire de ces expériences est que le système ganglionnaire, au lieu d'avoir des fonctions indépendantes, comme beaucoup d'auteurs l'ont avancé, serait, ainsi que les autres nerfs, une dépendence du système cérébro-spinal.'

10 Claude Bernard, 'De l'influence du système nerveux grand-sympathique sur la chaleur animale', C. r. hebd. Séanc. Acad. Sci., Paris, 1852, 34, 472f. See also, 'Note sur la multiplicité des phénomènes qui résultent de la destruction de la partie cervicale du nerf grand sympathique', op. cit., 1853, 36, 417: 'Je crois avoir, le premier, prouvé que cette destruction de l'influence transmise par le filet sympathique amène à sa suite une grande quantité de phénomènes très-differents, mais tous connexes et dépendants les uns des autres... 


\section{Reflections on Joseph Lister's Edinburgh Experiments on Vaso-motor Control}

the rise in temperature of the corresponding ear or side of the face of a rabbit, could be brought about equally well by the extirpation of a certain region of the spinal cord, namely that between the 'last cervical and the third pectoral vertebrae', ${ }^{20}$ the same region of the spinal cord from which those sympathetic fibres controlling the pupils took their origin before leaving the cord by the 'anterior' (motor) root. Clearly, the change in the temperature of the ear and facial parts of the rabbit was analogous to the syndromes of the eye. Neither effect was produced, except to a small extent, by sectioning the corresponding 'posterior' (sensitive) root of the spinal cord. ${ }^{21}$

Almost immediately, Budge wrote another note for Comptes rendus, in which he specially drew attention to the bearing of his research and that of Waller on the correction of contemporary theory, namely that the 'fibres forming the great sympathetic nerve, upon which the functions ascribed to the ganglionic system depend, originate only in ganglia'. One now knew with certainty, he wrote, 'that the fibres of the sympathetic nerve which are directed towards the eyes, take their origin in the spinal medulla'; furthermore, he had 'demonstrated the connection of the fibres directed towards the [blood] vessels of the head with the spinal medulla'. ${ }^{22}$

Meanwhile, Waller had published a long paper describing how the effects of sympathetic innervation or denervation could be varied at will. Division of the cervical sympathetic of such an animal as a cat produced the familiar contraction of the pupil of the eye, the encroachment over the cornea of the nictitating membrane, the reddening of the skin of the ear, and a rise in temperature of the affected parts. However, he claimed, if one stimulated the upper open end of the sectioned nerve, the induced effects were reversed: the pupils extended, the nictitating membrane withdrew, the blood-vessels became empty, and the skin regained its former temperature. ${ }^{23}$ He concluded that 'the flow of blood' and 'other phenomena of the same kind, are explained by the presence of channels whose dimensions vary according to the

20 Budge, 'De l'influence de la moelle épinière sur la chaleur de la tête', $C$. $r$. hebd. Séanc. Acad. Scl., Paris, 1853, 36, 377f.

3i Ibid: 'Après avoir mis à nu la région indiquée de la moelle épinière, j'en enlève une moitié à partir du dernier nerf cervical jusqu'au troisième nerf pectoral. En dix à quinze minutes, la chaleur de l'oreille du même côté a tellement augmenté, qu'on peut déjà remarquer la différence entre les deux oreilles en les touchant . . . La région de la moelle épinière ci-dessus mentionée est la même d'où les fibres du nerf grand sympathique dirigées vers l'iris prennent leur origine. Comme j'ai trouvé que le nerf grand sympathique de l'iris sort des racines antérieures (motrices) de cette région de la moelle épinière, j'ai aussi observé le même phénomène relatif à la chaleur; car si l'on coupe seulement les racines postérieures (sensitives), la chaleur de la tête n'est pas altérée ou ne l'est très-peu.'

28 Budge, 'Remarques à l'occasion d'une communication récente de M. Bernard', C. $r$. hebd. Séanc. Acad. Sci., Paris, 1853, 36, 575: 'Nous avons démontré la communication du grand sympathique dirigé vers l'iris, avec la moelle épinière; et moi j'ai démontré la communication des fibres dirigées vers les vaisseaux de la tête avec la moelle épinière'.

23 Waller, 'Neuvième mémoire sur le système nerveux', C. r. hebd. Séanc. Acad. Sci., Paris, 1853, 36, 378f: 'Lorsque on divise ou qu'on place une ligature sur le cordon cervical du sympathique, ou bien si on le soumet à l'irritation réitérée du galvanisme, l'ouverture pupillaire se contracte, la membrane nictitante s'avance sur la surface de l'oeil, et les vaisseaux de l'oreille en particulier deviennent plus rouges. La température de ses parties augmente d'une manière facile à apprécier à la main et au thermomètre ... Si l'on galvanise le bout supérieur du nerf, la pupille se dilate à son maximum, la membrane nictitante se retire dans l'angle de l'oeil, et en même temps si l'on examine les vaisseaux de la conjonctive ou de l'oreille, on voit qu'ils vident et que la peau et la membrane muqueuse reviennent à leur couleur normale ... En les (les pôles galvaniques) éloignant et en les appliquant alternativement au nerf, on fait paraítre ou disparaître à volonté les phénomènes oculaires et vasculaires. Pendant que les vaisseaux injectés se débarrassent du sang, la température de la peau s'abaisse, et j'ai pu, par ce moyen, faire descendre le thermomètre de 1 à $1 \frac{1}{\mathbf{z}}$ degré centigrade . . . 


\section{A. E. Best}

influence of the cephalorachidian axis'.24

Experiments carried out by such people as Brodie and Chossat, and confirmed by Brown-Séquard, had shown that an apparent rise in temperature of the legs could be brought about by cutting through the spinal roots of the sciatic nerve. Similar rises in temperature were also produced in other parts of birds and mammals by sectioning spinal motor roots. ${ }^{25}$ Moritz Schiff recorded a rise in temperature of the wings of bats, after the removal of the part of the spinal cord between the lower cervical and upper dorsal vertebrae. ${ }^{26}$ Not unreasonably, people were beginning to have doubts about the exclusively autonomic function of the sympathetic system. Budge was already suggesting that the whole sympathetic system might be an outflow from the spinal cord, though he cautioned that this 'suspicion would have to be proved for all the afferent fibres'. ${ }^{27}$

Now in pursuance of his personal interest in inflammation, as a surgeon, Lister had consulted a paper by $T$. Wharton Jones, in which a technique was described for studying the flow of blood-corpuscles through smaller vessels by means of a microscopic examination of the translucent web of a live frog. ${ }^{28}$ Commenting on Bernard's experiments on the cervical sympathetic nerve of a cat, Wharton Jones had explained the increased redness and warmth of the ear as a 'fuller' flow of blood 'in consequence of the arteries having become more dilatated from impaired contractility of their walls'. He was not able to confirm, however, that the control of blood vessels of the hind legs was dependent upon spinal centres. The arteries of the hind webs viewed under a microscope still retained their 'contractility' after the removal of the roots and part of the spinal cord 'supplying' the hind limbs. However, after he had sectioned the sciatic nerve 'as high up in the thigh as possible', he observed that the arteries of the web of the affected side were considerably dilatated. ${ }^{29}$ The 'relaxation of the muscular coat of the arteries', he wrote, 'appears to be the effect of the section of the sympathetic fibre bound up in the ischiatic nerve, and not of the section of the proper spinal fibrils of that nerve'.

This topic was much in Lister's mind during the first half of 1857. In a paper which he read to the Royal Society in the earlier part of that year, he referred to the contractile mechanism of smaller blood vessels, and he claimed that the 'contractions of arteries of the frog's web are regulated by a part of the spinal cord', the destruction of which 'is followed by permanent dilatation'.80 It would appear that at an earlier stage he meant merely to give his research on vaso-motor control as an appendix

« Ibid: 'L'afflux du sang . . . et tant d'autres phénomènes du même genre, s'expliquent par l'existence de canaux dont les dimensions varient suivant l'influence de l'axe céphalo-rachidien.'

25 . Brown-Sequard, Experimental Researches applied to Physiology and Pathology, New York, 1853, pp. 8, 75.

schiff, Gaz. hebd. Méd. Chir., 1854, $421 \mathrm{f}$.

27 Budge, C. $r$. hebd. Séanc. Acad. Sci., Paris, 1853, 36, 577: 'La science exige que l'on constate le meme fait pour tous les filets du grand sympathique avant que l'on puisse faire plus que soupconner que tout le nerf grand sympathique provient de la moelle epinière .... Budge's caution was probably because of the experimental findings of Brown-Sequard, C. r. hebd. Séanc. Acad. Sci., Paris, 1850, 30, 828f, that many of the functions associated with the sympathetic nerve-e.g., of the heart, bowels, lungs, urination, etc.-persisted 'sans trouble apparent' even after the destruction of a large part of the spinal cord.

ss Wharton Jones, 'Observations on the state of the blood and the blood-vessels in inflammation', Med.-chir. Trans., 1853, 18.

20 Ibid., p. $400 f$.

o Proc. R. Soc., 1856-57, 8, 583. 


\section{Reflections on Joseph Lister's Edinburgh Experiments on Vaso-motor Control}

to the paper which he presented to Philosophical Transactions under the title, 'On the early stages of inflammation'. During the summer months of 1857, however, he carried out further experiments on the neural control of arteries, so that when this finally appeared in Philosophical Transactions in the following year, it did so as a long, independent paper. Meanwhile, John Goodsir, who was one of the referees consulted by the editorial committee of Philosophical Transactions, had written to Sharpey pointing out that the methods employed by Lister in investigating vaso-motor control in the hind webs of a frog had already been in use in Germany. He wrote: ${ }^{31}$ 'He [Lister] does not appear to be aware of Pflüger's observations on the influence of the spinal motor nerves on the calibre of the blood vessels; which approach his own so closely that they must be referred to when the paper appears.' Evidently, this was passed on to Lister by Goodsir, for Lister acknowledged the coincidence between Pflüger's methods and findings and those described in the introductory paragraphs in his own paper, 'An enquiry regarding the parts of the nervous system which regulate the contractions of the arteries'.

It is difficult to decide whether Lister, whose source reference to Pflüger is only of a notice in Henle and Meissner's Bericht ${ }^{32}$ had read the full paper though he refers in his footnote to minor details which were to be found only in Pflüger's own publication. ${ }^{33}$ Edward Pflüger was primarily interested in the observable contractions of the arteries in the web or in the mesentery of the conveniently-large Rana esculenta whilst the 'anterior' (motor) spinal roots were being stimulated with an induced electric current, and this he had already described in somewhat earlier papers. ${ }^{34}$ However, the research to which Henle and Meissner's notice refers,-namely that in Pflüger's 1856 paper mentioned above-was an elaboration of his earlier procedure, and was intended to dispel the suggestion that these arterial contractions in the web

\footnotetext{
"11 Goodsir to Sharpey, 4 October, 1857, Edinburgh University MS., Dc. 4. 101.

22 Phil. Trans. $R$. Soc., 1858, 148, 608n. He merely cites the source of this notice in Henle und Meissner's Bericht über die Fortschritte der Anatomie und Physiologie (Leipzig and Heidelberg 1857, pp. 346ff.): 'Pflüger hat seine Versuche an Fröschen über die Einwirkung der vorderen Wurzeln der Spinalnerven auf das Lumen der Blutgefässe fortgesetzt und ist namentlich bemüht gewesen, diese Versuche von dem Verdacht zu reinigen, es möchte die beobachtete Verengerung der Arterien der Schwimmhaut und des Mesenterium bei Tetanisiren der vorderen Wurzeln etwa eine den secundăren Zuckungen vom Nerven oder Muskel aus analoge Erscheinung sein. Er benutzte grosse Frösche und legte die Electroden so an, dass ein beträchtliche Raum zwischen dem Körper und der demselben nächsten Electrode, dagegen nur ein kleiner Zwischenraum zwischen den beiden Electroden blieb. Die Wirkung der an sich schwachen Ströme wurde hierdurch noch mehr herabgesetzt, so dass keine secundäre Zuckung in dem angelegten Rheoskop hervorgerufen wurde. Die Arteriencontraction trat ein, und niemals, wenn in gleicher Weise die hinteren Wurzeln tetanisirt wurden. Um den Gedanken an secundäre Wirkung vom Muskel aus zu beseitigen, durchschnitt $P f$. den Stamm des Ischiadicus unter dem Abgange der Oberschenkeläste und tetanisirte dann den freigelegten Plexus ischiadicus, oder er tetanisirte den am Oberschenkel freigelegten Ischiadicus und beobachtete die von dem Gastrocnemius aus erfolgenden secundären Zuckungen am Rheoskop. Der Nerv desselben hörte bei Ermüdung des Muskels auf zu reagiren, während die Arteriencontraction 4 bis 6 Studen lang bei 3 bis 6 Minuten wiederholtem schwachen Tetanisiren beobachtet wurde, und zwar grade dann am schönsten, wenn die Muskeln schon sehr ermüdet waren. An den Venen wurde bald eine Veränderung ihres Lumens beobachtet, bald nicht, bald wurden sie etwas weiter, bald etwas enger, und meint $P f$., dass ein Einfluss von den vorderen Wurzeln aus jedenfalls so klein sei, dass er durch andere Circulationsstörungen von Skelettmuskeln oder Arterien aus, versteckt werde.'

${ }^{23}$ E. Pflüger, 'Dritte Mittheilung über die Einwirkung der vorderen Rückenmarkswurzeln auf das Lumen der Gefässe', Allg. med. ZentZtg., 1856, 25, $249 \mathrm{f}$.

"Ibid: 'In den beiden vorhergegangen . . . Mittheilungen war gezeigt worden, dass die Arterien der Schimmhaut ... ihr Lumen verkleinern, wenn man die vorderen Wurzeln der Rückenmarksnerven mit Inductionsströmen tetanisirt . . .
} 


\section{A. E. Best}

were due, not to direct stimulation of the spinal nerves, but to local motor effects ('secundäre Zuckungen'), brought about, presumably, by peripheral nerves. In other words, what Pflüger was hoping to show conclusively was that such arterial contractions were effected by nerves whose superficial origin was in the spinal canal, and not by a strictly autonomous nervous system with its own ganglia, which might respond to stimulus independently. To satisfy himself on this point, he first employed a technique of directing only very small currents across short paths on the roots of the spinal nerves, so that only the spinal nerves would be stimulated and any secondary effects eliminated. He observed that by thus stimulating the 'anterior' roots which supplied the sciatic plexus, the arteries of the web contracted. However, as no contraction followed the stimulation of the 'posterior' (sensitive) roots-which might have been expected, if these contractions had been a 'secondary' effect-Pflüger judged that the vessels were under the control of spinal nerves. ${ }^{35}$ There remained the possibility that arterial contractions might be part of a 'secondary' muscular convulsion, and to decide this he adopted the technique of inducing fatigue in those muscles which were innervated by the sciatic nerve through prolonged electrical stimulation; he argued that any induced change in the diameter of the vessels following upon such frequently repeated stimulation, would hardly be a 'secondary' convulsive response. Yet he found that he could bring about successive vascular contractions in the web many hours after the sciatic nerve had ceased to produce significant responses in the muscles of the thigh. ${ }^{36}$ (As well as the arteries, the veins also were seen to respond to electrical stimulation, though the variations of their diameters were erratic and never very considerable.)

Pflüger's conclusion that vaso-motor control is through fibres in the spinal cord clearly anticipated certain of Lister's experimental findings. For instance, Lister's research indicated that some vaso-motor fibres passed out of the spinal canal through roots of the sciatic plexus. There were, however, important differences, both in their methods and in their final conclusions. Lister's principal conclusions were based on a technique of denervation, and one of the more important facts which was brought to light by his experiments was that even after the section of the nerves which supplied the hind limb of the animal, and even after the removal of portions of the spinal cord, the arterioles of the webs which were under observation eventually recovered their contractility. Indeed, even after the complete detachment of the hind limb, the diameters of these smaller blood vessels were still seen to undergo wide fluctuations, and by the time that Lister had completed the sequence of experiments published in Philosophical Transactions, he was prepared to entertain the possibility of some kind of arterial control by means of nerve-ganglia which as judged histologically were independent of the central nervous system.

Lister's experiments on vaso-motor control, which were performed in Edinburgh, began in the late autumn of 1856 , and they continued-though with long intervening breaks, if one may judge from those that were published-until the autumn of the following year. Throughout the series, the animal used was the British common frog.

s5 Ibid: 'Endlich aber wurde niemals eine Spur von Wirkung wahrgenommen, wenn bei der von uns befolgten Versuchsweise statt der vorderen die hinteren Wurzeln auf die Bleche aufgelegt waren $\therefore$

se Ibid. 


\section{Reflections on Joseph Lister's Edinburgh Experiments on Vaso-motor Control}

With occasional modifications his method consisted of tying out the toes of both feet on the stage of a microscope, in such a way that the corresponding arterioles of the right and left webs could be brought successively and rapidly into view, and the affected and unaffected sides compared directly. Using a succession of such frogs, each anaesthetised-or in some cases paralysed by the section of the top of the spinal cord - with their hind webs laid out in the manner described, he carried out his separate experiments. These experiments consisted of sectioning or ligating or stimulating the selected nerve-trunk or sectioning or stimulating a selected region of the spinal cord. Also, in some cases he stimulated or destroyed different parts of the brain. In each case, he observed the pre-selected arterioles and calibrated their varying diameters after suitable intervals of time with a glass eye-piece micrometer, his results being recorded as 'degrees' of the micrometer-scale. These numerical results, which were only comparative, of course, varied from almost zero when there was closure, to an approximate maximum of 4 degrees for complete dilatation. The 'normal' diameter of the vessels which he chose for observation was about $1 \frac{1}{2}$ degrees. His observations varied in number and duration from one experiment to the next. One of his expressed difficulties was in deciding where to cut open the back of the animal, in order to section or to remove a portion of the spinal cord without causing too great a loss of blood. Accordingly, he employed a technique of judging the exact location in the spinal cord as a fraction of the distance between the easily-felt back edge of the scapula and the front end of the sacrum. In some cases, however, he dissected the animal after the experiment to confirm his original calculation. Unless otherwise stated, therefore, his initial procedures were those described above. Lister did not assign numbers to the experiments mentioned in his paper. Indeed, during this period, he probably performed more experiments in this field than those published. We are using a convention of number to facilitate reference in our paraphrased summary of his published paper:

\section{Experiment $1^{37}$}

Having observed the arterioles of the hind webs for some time in order to judge their variations, Lister isolated from its adjoining tissue the sciatic nerve on one side, and ligated it. The selected arteriole on this side immediately contracted, after two minutes it was wider than before the cutting began, after thirty minutes it had contracted to normal diameter, but shortly afterwards it was again very constricted, and it remained thus even after the severance of the nerve above the ligature. During the next twenty four hours, however, there were wide variations of calibre. He noticed that full constriction, which appeared to accompany the struggles of the frog, occurred on the unaffected, as well as on the affected side. Evidently, the sectioning of the sciatic nerve did not lead to permanent dilatation, and thus the findings of Wharton Jones, that the arterioles received sympathetic innervation from extensions of the sympathetic system which accompanied the sciatic nerve, were provisionally refuted.

\section{Experiments 2 and $3^{38}$}

In each of these two experiments, Lister opened the spinal canal and sectioned the spinal roots, on the left side in one case and on the right side in the other, 'from the occiput to the sacrum'. The effect in the first experiment was an immediate constriction of the arterioles on the unaffected side, and a gradual widening to full distension of the corresponding vessels on the affected side. Some hours later, however, the arterioles on the affected side had resumed their normal calibre. Lister observed during the third experiment that there was no widening of the arterioles whilst he was actually cutting through the spinal roots, until he severed the roots of the sciatic

37 J. Lister, 'An Enquiry regarding the parts of the nervous system which regulate the contractions of the arteries', Phil. Trans. R. Soc., 1858, 148, 609. Experiment performed, 27 October 1856.

so Performed respectively, 8 and 11 April 1857. 


\section{A. E. Best}

plexus, when there followed considerable dilatation on the affected side, but again he noticed that these much widened vessels eventually contracted to what was almost their normal tone. Though sufficiently convinced that it was the 'spinal system' alone which controlled the diameters of these observed arterioles, Lister was obviously puzzled by this apparent recovery of tone after such extensive cutting of the spinal roots-from the hypoglossal, presumably, to the root which emerges from the side of the urostyle-and he was evidently relieved by the fact that some of the nerve-fibres between the spinal cord and the sciatic plexus had been overlooked and still remained intact.

Experiments 4, 5 and a repetition

Basically of course, Lister's technique was to demonstrate the source of vascular innervation by severing or destroying selected nerve-fibres until permanent dilatation was obtained. So far, apart from an inconclusive refutation of Wharton Jones, his own results seemed to be equivocal. Accordingly, he decided to go at once to the most obvious source of innervation and to study the effects of stimulation. He opened the cranium and probed the 'cerebral hemispheres' with a fine needle, but the arterioles, which were now fully extended, did not change. On probing the posterior 'dark coloured portion of the brain', which included the optic lobes, cerebellum and medulla oblongata, he obtained a contraction of the arterioles, though after the withdrawal of the needle this was soon followed again by full dilatation. He then repeated this whilst observIng another web, and again he obtained almost complete constriction of the arteriole during stimulation of the back part of the brain, and complete dilatation after the needle had been withdrawn. This continued until the brain parts had been completely broken up by continued probings, when the arterioles were no longer responsive and remained permanently distended. Stimulation of the open, anterior end of the spinal cord, however, still produced immediate contraction of the vessels. Such stimulation, as distinct from denervation, strongly suggested that vascular contraction was fully controlled by the cerebro-spinal system.

Experiments 6 and $7^{\text {to }}$

On sectioning the spinal cord of a frog between the back of the skull and the first vertebra, Lister observed that the arterioles distended and then gradually regained their normal calibre. (Experiment 6) Indeed, even after the removal of the entire brain of an anaesthetised animal (Experiment 7) he found that the arterioles, which dilatated widely for a short time, finally returned to their normal calibre of between $1 \mathrm{t}$ and 2 degrees. However, he could still produce successive contractions and dilatations of these arterioles by probing the open end of the spinal cord with a bent needle.

There was clear evidence of a 'centre' in the cerebro-spinal axis which ultimately controlled the calibre of the arteries of the web, but the question still remained as to where such a centre was located, whether it was in the brain from which it directed its extensions down the spinal cord, or whether it was actually in the cord itself. Also, it was again becoming an open question whether a 'similar (controlling) office might not . . . be discharged by some of the sympathetic ganglia'.

Lister knew, of course, that the principal roots for the hind legs-those which are now conventionally numbered $8,9,10$, and 11 in the case of the frog, and which contribute to the sciatic plexus-arise from the end-segments of the cord. He had observed also that there were connecting fibres between these and the roots which arise a 'short distance forward from the middle of the cord' to supply the 'abdominal parietes'. Accordingly, he employed the method outlined above to estimate the exact point along the spinal cord at which a cut could be made most economically without extensively opening up the back of the animal. By this means, starting from the top of the spinal cord, he removed one-sixth of its length. First, there was an immediate and complete constriction of the arteriole, then, after a few minutes, it began to dilatate reaching its full extent of 3 degrees in about 10 minutes. Finally, the vessel recovered its normal tone, the calibre varying between $1 \frac{1}{2}$ and 2 degrees.

Removing the next vertebral arch, Lister cut out from the open front of the spinal cord a further one-twelfth of its length-so that, by now, about a quarter of the whole cord had been removed. Again, there was temporary contraction immediately after the sectioning of the cord, which was followed by some dilatation, and finally a return to the nearly normal diameter of between 1 and 1 f degrees. He then removed the segment of cord corresponding to the next vertebral

20 Performed, 14 April 1857.

10 J. Lister, op. cit., p. 611f. Experiment 6, which is described in a footnote (p. 611), is of the same principle as Experiment 7, though the employment of spinal transection instead of chloroform, may indicate that it was performed at a later stage. Systematically, however, it follows Experiment 5. 


\section{Reflections on Joseph Lister's Edinburgh Experiments on Vaso-motor Control}

arch, and, again, there was the same sequence of contraction, dilatation and eventual return by the observed blood vessel to a normal tone of $1 \frac{1}{2}$ degrees.

He then removed another vertebral arch and partly divided the cord at the point corresponding to the far back edge of the scapula, that is, a little beyond the mid-point of the cord. After 20 seconds the arteriole was oscillating between 1 and $1 \frac{1}{\text { or }} 11$ degrees. Now he completely sectioned the cord at this place. Within two minutes the arteriole had fully closed, though it regained a calibre of $1 \frac{1}{\mathrm{~b}}$ degrees after four minutes. The heart of the frog was now beating feebly and the blood circulation was very slow. Lister then detached the isolated piece of cord from its emerging roots and removed it completely from the spinal canal. The blood-flow, he recorded, had now stopped through the 'feebleness of the heart', but the observed blood-vessel had dilatated $1 \mathrm{f}$ degrees.

His conclusion from this experiment (Experiment 7) was that the front third of the spinal cord appeared to contain centres-or, at least, $a$ centre-of vaso-motor control, but that these were not the only centres of such control: stimulation of any part of the front half of the spinal cord produced some constriction, followed by dilatation in the arteries of the feet. ${ }^{11} \mathrm{He}$ surmised, however, that the weakening of the heart and the impaired circulation might mask the effect of denervation of these smaller blood-vessels. Hence he adopted another procedure.

\section{Experiment $8^{42}$}

Having removed the vertebral arch 'opposite the junction of the middle and posterior third of the scapula', he sectioned the exposed spinal cord just in front of its mid-point. After a few minutes the arteriole of the web which he had selected for observation had regained approximately its normal calibre. He recorded that the blood circulation was rapid. Then the next arch was removed and the cord sectioned as far as it was exposed, but the isolated portion of cord was not extracted from the canal. Complete closure of the arteriole followed, but there was a slight dilatation after ten minutes. The isolated piece of spinal cord was then detached from its roots and taken out of the canal. It was observed that the selected arteriole began to expand slowly, and in two minutes blood-vessels were again flowing through, though even when the calibre was $1 \frac{1}{2}$ degrees, there was still only a very weak circulation. However, on stimulating with a needle the exposed open end of the posterior portion of cord still remaining in the canal, Lister observed that the arteriole had closed up and that the blood was actually being forced backwards. Dilatation began after 15 minutes, and for the next one and a half hours the calibre oscillated between $t$ and 11 degrees. He then removed the vertebral arches and all the remaining posterior part of the cord and the cauda equinae. Immediate and apparently permanent dilatation followed in all the arteries of the web, and even prolonged mechanical stimulation of the anterior cord and brain failed to produce any further change in the diameter of these blood-vessels.

This indicated for Lister that the posterior part of the cord 'certainly contains a nervous centre for regulating the contractions of the arteries of the foot', such contractions that resulted from the stimulation of the front part of the cord, occurring only because of its connections in the rear part of the spinal cord with the roots which emerge to supply the hind limbs. He argued that if the brain and the front part of the cord innervate the arteries of the foot, they do this not through any connections with the sympathetic nerve, but through the nervous outflows from the posterior parts of the spinal cord."s

Experiment 94

Lister then went on to consider whether there was other 'ganglionic apparatus' besides the 'cerebro-spinal axis' which innervated the arteries of the feet. First, he removed the appropriate vertebral arch and divided the cord opposite the hindmost edge of the scapula - that is, a "little behind' the mid-point of the spinal cord. Constriction of the arteriole followed. Then the posterior half of the spinal cord, the roots supplying the hind limbs, and the cauda equinae were removed. After a brief period of contraction, the observed arteriole widened to 3 degrees. Lister observed,

11 Lister explained in a footnote that the "transient character of the effects produced upon the arterial calibre by these operations led me at first to conclude that the anterior parts of the cerebrospinal axis did not contain any nervous centre for the arteries, and this view was expressed in the original manuscripts'. His 'opinions on this point ... . however, [were] altered by . . . subsequent experiments . ... at the conclusion of the paper.'

"s Performed, 18 April 1857.

63 J. Lister, op. cit., p. 616: : . . the brain and the anterior part of the cord . . . do not exert that influence [on the arterioles] through the branches which connect them with the sympathetic, but only through ... the more posterior parts of the cord.'

A Experiment performed, 2 June 1857. 


\section{A. E. Best}

however, that this was not the limit of dilatation, for on sprinkling the foot with hot water he saw that the same arteriole had dilatated to 4 degrees, though it returned again to its static diameter of 3 degrees. This experiment was repeated several times with the same result.

He then extracted a piece of the remaining cord as far as the 'anterior third of the scapula'. There was a further widening of the arterioles in each limb to between 3 and 4 degrees, and this in spite of the enfeebled heart-bearts and slow blood circulation. Subsequent removal of the rest of the spinal cord and of the entire brain caused no further change in the calibre of the arterioles, which then remained fully distended. Evidently the arteries of the foot retained some degree of contractility even after the removal of the rear of the cord and of the principle roots for the hind legs, but when the region anterior to the mid-point of the cord was removed, the vessels remained permanently extended. From this fact, Lister was led at first to conclude that 'there existed no other ganglionic apparatus for the arteries of the feet than that contained in the cerebro-spinal axis'.

Experiment 10 and repetitionse

Lister now turned his attention to the problem of where precisely within the spinal cord were located the centres which controlled the calibre of the arteries of the feet. If these centresor the centre-were near to the middle of the spinal cord, then the removal of a sizeable piece of the cord across the mid-point might be expected to bring about the denervation of the arterioles of the feet. He sectioned the spinal cord at about a quarter of its length from the posterior end, recorded the fluctuations in the arteriole, sectioned the cord at the same distance from its anterior end, and again recorded the fluctuations in the arteriole. Then he took out the piece of cord between the two transections, that is, about half the total length of the cord, and recorded the fluctuations in the same arteriole-which were varying between a calibre of 1 and $1 \frac{1}{2}$ degrees after about twelve minutes. Now the heart was beginning to weaken, though about half an hour later the calibre of the arteriole was still fluctuating between 2 and $2+$ degrees. On the removal of the posterior end of the cord, the arteriole remained dilatated at $2 t$ degrees, or slightly more, until the blood circulation had ceased. Evidently the middle part of the cord was not essential to vaso-motor control.

This experiment was repeated almost at the end of the series. First, the cord was transected at about one-fifth of its length from the posterior end. Immediately after, the calibre of the selected arteriole was found to be 21 degrees. It was observed that the circulation was normal. Next, the cord was transected at about a quarter of its length from the anterior end. A few minutes afterwards the arteriole had a diameter of $1 \mathrm{t}$ degrees. Again the intervening piece of cord was removed, during which it was noticed that, whilst a 'large root' for the hind limb was being severed, there was an immediate distension of the arteriole to $2 \mathrm{t}$ degrees and a quickening of the flow of blood. ${ }^{17}$ Soon, however, the vessel contracted to 2 degrees. On probing the exposed end of the anterior segment of cord, Lister observed convulsive responses in the fore-limbs, but no change in the calibre of the arterioles of the hind limb. The heart was now beating feebly, but it recovered during the night, and, on the next morning, the blood-circulation was steady, whilst an observed arteriole had dilatated to $3 t$ degrees.

The remaining posterior part of the cord was, apparently, still regulating arteries, because after its complete removal the selected blood-vessel had extended to a permanent 4 degrees. But the previous experiment had indicated that the removal of the greater part of the posterior cord did not lead to complete de-control of the arteries. Hence Lister concluded that the centres which regulate the calibre of these arterioles in the hind-limbs were not limited to any one region of the cord, since a 'small piece of the cord' would 'suffice to regulate the calibre', whilst only a 'little effect' might be 'produced, even in the first instance, by the removal of a large portion which also' had 'that (regulating) function'.8 Evidently the removal of the middle segment of the spinal cord had left these arterioles completely under the control of the posterior fifth of the spinal cord. He argued that the anterior part of the cord did have some degree of control, provided that the rest of the cord remained intact with its roots, for any control from the anterior part of the cord could operate only 'through those roots of the nerves which emerge from the posterior parts of the cord'.

Lister was impressed by the facts that the partial severance of the spinal cord still left the bloodvessels of the hind-webs sensitive to the stimulation of the upper part of the cord, and that the complete section of the sciatic nerve had only a temporary effect upon the contractility of

«s J. Lister, op. cit., p. 617.

- Performed, 26 August and 20 October 1857, respectively.

$17-$ on his cutting, presumably, the 8th spinal nerve. (A.E.B.)

18 J. Lister, op. cit., p. 622. 


\section{Reflections on Joseph Lister's Edinburgh Experiments on Vaso-motor Control}

these vessels. Hence he surmised that even a 'few fibres of the nerves for the blood-vessels ... can supply the place of the rest more perfectly than is the case with the ordinary nerves of sensation and motion'.

\section{Experiment $11^{\circ 0}$}

Lister then extended the scope of the enquiry by dividing all the soft parts of the mid-thigh of a frog with the exception of the main artery and vein. He recorded full dilatation of the bloodvessels of the webs. After $\mathbf{2 4}$ hours, he noticed that these vessels had contracted to 'moderate size', though the circulation was still continuing vigorously. Following the death of the animal, he examined the tunics of the arteries and veins, the periosteum and the attached muscular tissue, but he could find no nervous tissue in them. However, he conjectured that there might still be 'slender filaments' in the coats of the blood-vessels-or even in the bone-which allowed communication between the cerebro-spinal axis and the arteries of the web.

Experiment $12^{\text {s0 }}$

He repeated Experiment 11 on both thighs, recording the dilatation of selected arterioles immediately after the transection of the nerve-fibres. Again, he observed that the vessels contracted to a normal calibre of between 1 and 2 degrees after 16 hours, which appeared to indicate that these vessels were still under the control of the spinal cord.

Experiment $13^{51}$

On repeating the procedure of Experiments 11 and 12, and, at the same time, extirpating the whole of the brain and the spinal cord, he observed that the arterioles became fully distended and that they did not vary until the death of the animal.

Supporting experiments and observations

It is evident that other experiments of this kind were undertaken by Lister during this period. Whilst investigating something else, ${ }^{52}$ he had occasion to amputate the leg of a frog across the thigh, the blood being retained in the limb by a tight ligature just below the place of severance. An immediate view of the arterioles of the webs found them to be fully distended at $4 \frac{1}{2}$ degrees, but this was only temporary for there were considerable variations of diameter along the length of observed blood vessels during the following eight days. Lister was obviously puzzled by this occurrence, which was so obviously at variance with what he was hoping to establish by Experiments 2, 3, 4, and 5, carried out very shortly afterwards. His realization that what he observed in the vessels of the amputated limb, might be relevant after all, came at the end of the sequence of his research on vaso-motor control. He was now satisfied that full dilatation would take place only if there was a sufficiently sustaining pressure of blood, such distension being merely a passive response of the walls of the vessels to the pressure exerted. Yet even after the complete extirpation of the brain and the spinal cord, even after the blood had ceased to flow, there were still anomalous variations of the diameter of the arterioles. ${ }^{38}$ These differed from the usual variations, however, by the complete lack of unison, since the wide variations occurred, not only from one vessel to another, but from one part of the same vessel to another part along its length.

Lister was forced to conclude that changes of calibre of these vessels could take place even when there was no longer any nerve-connection, either with the spinal roots or with the sympathetic ganglia within the trunk of the animal. He suggested, however, that there might be some "coordinating' mechanism in the severed limb, capable of effecting convulsive movements of the blood-vessels similar to those which had been described by Meissner as controlling the plain muscle-fibre of the intestinal wall, even after the circulation had ceased; ${ }^{34}$ that although the constriction of blood-vessels was normally brought about by 'centres' in the hind part of the brain and along the length of the spinal cord, there was also in the limb a 'means' by which the 'fibre-cells of the circular coat of these vessels might contract in concert'. Such a means, he assumed, was very probably 'ganglionic', and could function independently and even in complete isolation from the rest of the nervous system.

Of course, we now know that throughout these experiments there were several uncontrolled factors, and that what Lister observed were not always the simple

1 Performed, 10 October 1857.

$6 \mathrm{~J}$. Lister, op. cit., p. 623. Experiment performed, 13 October 1857.

61 Performed, 13 October 1857.

62 -i.e. on 2 April 1857

6s Observed, 23 October 1857.

* G. Meissner, Z. rat. Med., 1857, 8, 364. 


\section{A. E. Best}

direct sequences, which he took them to be. Such extensive cutting of the spinal roots in Experiments 2 and 3-of which the upper ventral roots are known to contain pre-ganglionic autonomic fibres-would certainly show the effects of vaso-denervation, though some of Lister's observations would require detailed interpretation. The fact that in Experiment 3 he saw no sign of such denervation until he had severed the 'roots of the sciatic plexus', was probably due to his cutting the upper spinal roots in such a way as to leave the connections of the white rami intact, in which case, there would be no vaso-denervation in the hind limb until he had reached the nerves which receive vaso-constrictor fibres in the grey rami from ganglia of the sympathetic trunk.

The destruction of autonomic cells in the hind brain in Experiments 4 and 5, and in the spinal cord in later experiments, would be expected to bring about the immediate constrictions and subsequent dilatations observed by Lister, though of course, he would not have tolerated any suggestion that these 'centres' were autonomic in the sense that they were part of the sympathetic system. Similarly, the sectioning of autonomic fibres within the spinal cord, which was what, in fact, took place in the course of Experiments 6 to 10, would produce, first, the effect of vaso-constriction (through the stimulation of cutting) and, second, that of gradual dilatation (through denervation), and these effects were described by Lister, though, as elsewhere, his explanation assigned no part to the sympathetic nerves.

There were many inconsistencies in his observations. The almost certain disruption of the vagus in Experiments 6 and 7 and the subsequent parasympathetic denervation of the heart, the great loss of blood through cutting, the absorption of chloroform by the blood-stream, the irritation of the skin by chloroform-vapour, ${ }^{55}$ the concentration of carbon dioxide in the slowly circulating blood, the hormonal secretions during periods of stimulation of the adrenal processes, would all have their effect, directly or indirectly, upon the calibre of the smaller blood-vessels. In explaining the changes of calibre of arterioles on the unaffected side of the frog in Experiment 2, one would have to consider, presumably, the presence of slender fibres, whichcertainly in the case of amphibia-cross over from the sympathetic trunk of one side to that of the other.

Lister was aware that the dilatation of the arterioles of the webs might well have been a passive distension to the pressure of the blood, but throughout his experiments his thoughts were dominated by the principle that muscular tissue, including the vascular muscle-tissue, whose presence in the middle coat he had so carefully and elegantly confirmed by microscopic examinations, was stimulated to contract only by nervous action. Accordingly, although he observed in Experiment 1, for instance, that the excitation of the animal was followed by the restriction of arterioles, irrespective of whether the connecting nerves were intact or sectioned, he never adumbrated that these constrictions were due to the introduction of some agent into the blood stream. Even after he had gone to great pains to destroy all perceptible nerve-connections leading to the arterioles of the web, he still chose to explain their returned tone through hidden nerve-centres, in spite of the fact that his 'post mortem' dissection showed no sign of their presence. Although what he observed in his experiments,

${ }^{\text {s5 }}$ Lister suspected that chloroform had this effect (Phil. Trans. R. Soc., 1858, 148, Pt. 2, 658.) 


\section{Reflections on Joseph Lister's Edinburgh Experiments on Vaso-motor Control}

and what he had discovered through his histological examination of the plain musclecells in the middle coats of the smaller arteries, seemed to lead to the almost inescapable conclusion that such cells were capable of self-contraction in response to certain stimulus, even after the connecting nerves had been destroyed, he simply dismissed the matter by a vague appeal to the network of nerve-fibres and ganglia discovered by such people as Meissner and Werner within the intestinal wall. ${ }^{56}$ As a superb microscopist, Lister had no justification for such an assumption with respect to the plain muscle-fibre of the smaller blood-vessels of the web. His unwillingness to conceive any kind of muscular activity except through mediating nerves can be understood only in the light of mid-nineteenth-century physiology.

Involved in Lister's Edinburgh experiments on vaso-motor control was a controversy which had been debated since the middle of the eighteenth century, and which was still a living issue when John Hughes Bennett was writing his article, 'Physiology', for the eighth edition of the Encyclopaedia Britannica, which was published in Volume XVII during 1859. He wrote:57 'The view originally put forth by Haller as the explanation of contractility was, that it was a vital power inherent in the tissues which possessed it; in short, an ultimate fact in physiology; a view which is supported by all that is known of the subject.' Whatever might have been the case among physiologists on the European continent, certainly, in Britain at least, the interest had endured beyond the early $1830 \mathrm{~s},{ }^{58}$ and it would be absurd to suppose that it had escaped the attention of Lister during his medical education. Basically, the controversy was concerned with the property of 'irritability', the supposed automatic response of muscular tissue to certain kinds of external stimulus. Originating in the vitalistic theories of Stahl and certain of his predecessors-partly in reaction to Cartesian 'mechanism'- the doctrine of 'irritability' was explained by Haller, who had derived the term from Francis Glisson, as an inherent property of muscular fibres, especially those of the visceral tissue, which caused them to undergo contractions when stimulated; and carefully distinguished from this inherent property were the contracting forces which acted upon the muscle-tissue through the mediation of nerves, or simply through the direct effect of physical conditions, which could be seen in the contractions of slivers of dead muscle. During the later part of the eighteenth century, the theory was also applied to vascular tissue, especially by such writers as Christian Kramp, who considered the topic at some length in his Dissertatio inauguralis medica de vi arteriarum (1785). ${ }^{59}$

A flow of authorities from E. Vallie0 and R. Fowler ${ }^{61}$ in the late eighteenth century,

6s See G. Meissner, op. cit; also see the notice in Z. rat. Med., 1858, 3, 184: 'Meissner machte die Entdeckung dass die sogen. Tunica nervea des Darms zahlreiche mikroskopische Nervenästchen enthălt. Diese bilden durch vielfache Anastomosen Gefiechte and die feineren daraus hervorgehenden Zweige scheinen hauptsächlich in die Muskelhaut einzudringen ... In grosser Menge sind überall Ganglien in die Plexus eingelagert.' (italics added).

${ }^{67}$ p. 652.

s8 - later, for instance, than 'das beginnende zweite Drittel des 19 Jahrhunderts' stated by P. Diepgen, Geschichte der Medizin, 1949, vol. 2, p. 19 f.

${ }^{80} \mathrm{p}$. 27f. Especially from 'Utique vis ...

co E. Valli, Experiments on Animal Electricity, London, 1793, p. 21.

$1 \mathrm{R}$. Fowler, Experiments and Observations relative to . . . Animal Electricity, Edinburgh, 1793, p. 109. 


\section{A. E. Best}

and Nysten ${ }^{62}$ in the early nineteenth century, to Matteucci ${ }^{68}$ in the late 1840 s described experiments in support of the doctrine of 'inherent contractility'. Thus Nysten claimed that in all vertebrate animals contractions could be produced by direct stimulation of the muscle fibre, for a long time after the nerves supplying these fibres had ceased to function, and Matteucci, that in animals killed by hydrocyanic acid, an electrode, whilst causing only very slight contractions when applied to the supplying nerve, would bring about strong convulsions when applied directly to the muscular tissue. John Reid carried out experiments on such animals as frogs and rabbits; the results of which were presented to the British Scientific Association in 1835. ${ }^{64}$ These experiments tended to show that 'contractility' would 'reappear in the muscles of a limb . . . which had been previously exhausted, and when the nervous connection between them and the central organs of the nervous system had been broken through'. He also tried to show that, in cases where the muscles of paralysed limbs appeared to lose their contractile response to electrical stimulus, this could be explained by the prolonged inactivity and attentuation of the muscular fibres through lack of nutrition. W. H. Madden, who carried out similar experiments on frogs, concluded that 'nerves cease to have any power of exciting contractions long before the muscles themselves have lost their irritability', but he would not go so far as to say that such contractions were independent of all 'nervous influence'.65 William Bowman, shortly before 1840 , claimed to have seen separate fasciculi of muscle which were undergoing contractions, after they had been completely isolated from nervous and vascular tissue. Thus, he wrote, the 'property of contractility is inherent in the very structure of muscle' and is 'capable of being called into action without the immediate instrumentality of nerves': such contractions could occur in response to water and even to foreign matter. Similar observations had been made by Longet ${ }^{66}$ on dogs and rabbits, in which it appeared that irritants applied to the open ends of severed nerves failed to produce muscular contractions long before they ceased to do so when applied directly to the muscles themselves. Hermann Stannius ${ }^{67}$ obtained similar results and, contrary to the views of others, came to the conclusion that 'muscles indeed possessed a characteristic contractility, which was independent of nerves'.

Even as late as 1853 , highly respected text-books were still being published in Britain, in which the doctrine of 'irritability' was stated as a fact beyond dispute. In one such manual we read: ${ }^{68}$ 'All muscular fibres which are in possession of vital activity, may be caused to contract by stimuli directly applied to themselves; and these stimuli may be of different kinds. The simplest is the contact of a solid substance, especially if it be pointed ... Most substances of strong chemical action, such as acids and alkalies, will excite the fibres to contraction, when applied directly to themselves; but the most powerful agent of all is electricity.' Yet, during the same period, there was considerable reserve on the part of many physiologists in attaching

'2 P-H. N. Nysten, Recherches de Physiologie et de Chimie pathologique, Paris, 1811, p. 369.

* M. Matteucci, Lecons sur les Phénomenes physiques des Corps vivants, Paris, 1847, p. 239.

4 Trans. Brit. Sci. Ass., 1835, 4, 671.

- L'Examinateur médical, December, 1841.

-7 Froriep, Neue Notizen aus dem Gebiete der Natur-und Heilkunde, 1842, 418, 336. 'Ich habe mich vielmehr überzeugt, dass die Muskeln wirklich eine ihnen eigenthümliche, von den Nerven unabhängige Contractilität besitzen.' (Italics added).

os W. B. Carpenter, Principles of Human Physiology, 4th ed., London, 1853, p. 309. 


\section{Reflections on Joseph Lister's Edinburgh Experiments on Vaso-motor Control}

such far-reaching theoretical importance to the much-quoted results of these Hallerian experiments. Marshall Hall, for instance, was impressed by the fact that there was no response to direct electrical stimulus applied to the muscles of the hind limbs of frogs, in which the 'excito-motory' nerve-connections had been sectioned, ${ }^{60}$ and he concluded that the source of 'irritability'-as distinct from 'acts of volition', which originate in the cerebrum-is located in the spinal marrow. ${ }^{70}$ The same signs of diminished 'irritability' were also observed by J. Müller in the leg muscles of small mammals whose sciatic nerves had been cut through, and he was led to the same conclusions as Marshall Hall with respect to the validity of the doctrine of 'irritability'. ${ }^{71}$

The debate which concerned the contractility of blood-vessels was an outgrowth of the Hallerian controversy. During the second decade of the nineteenth century the fact of arterial contraction had aroused the interest of such physiologists as $\mathbf{C} . \mathbf{H}$. Parry, who wrote two books, famous in their day, in which he described his experiments on blood-vessels. ${ }^{72}$ Even Hallerians were by no means agreed on the 'irritability' of vascular tissue. Bichat, writing in the first years of the nineteenth century, refused to distinguish between 'irritability' and 'tonicity' in relation to the blood-vessels, and he explained the two as contractilité organique, which he conceived as varying from that which 'presides in the heart and in the larger vessels to that in the capillaries, where only tonicity is observed.' 73 But he claimed that when removed from the body, the arteries showed no signs of contractility-for instance, a finger when inserted into the lumen of the vessel was not compressed, and even when dissected, layer by layer, the fibres of the vessel did not palpitate. Also, he maintained that arteries were not responsive to mechanical or electrical stimuli. Magendie, writing in the early $1830 \mathrm{~s}$, agreed with this. 'I am far from being in accord', he wrote, 'with some authors of the last century that they [arteries] dilatate by themselves, and that they contract in the manner of muscular fibres. On the contrary, I am convinced that they are passive in each case, that is to say, their dilatation and their narrowing (resserrement) are only a simple effect of the resilience of their membranes, called into play by blood, which is being continually forced into them by the heart'. ${ }^{74}$

Throughout the period of this dialogue, microscopes were being used more and more to settle points of anatomical and physiological dispute. To judge the full extent of this, one has only to glance at the manuals and papers on the use of the microscope which were written by such people as Carpenter, Purkinje, Henfrey and Quekett. For the first time, many facts, long in dispute, were being stated not with caution, but with categorical assurance. ${ }^{75}$ Even by 1837 , descriptions of the structure of the walls of arteries and veins were appearing, not merely in the less accessible journals, but in text-books widely used in medical education. Thus, in the 4th edition of Jones Quain's Elements of Anatomy, the middle coat of the artery is described as

"Med.-chir. Trans., (2nd ser.), 1839, 4, $191 \mathrm{f}$.

${ }^{70}$ Op. cit., p. 216.

71 J. Müller, Elements of Physiology, tr. Baly, 2nd ed., pp. 460 and 680.

72 C. H. Parry, An Experimental Inquiry into the Pulse and other Properties of the Arteries ..., Bath, 1816, p. 47ff; Additional Experiments on the Arteries . . , London, 1819 p. $98 \mathrm{ff}$.

7 M. F. X. Bichat, Recherches physiologiques sur la Vie et la Mort, Paris, 1805, p. $94 f$.

74 F. Magendie, Précis élémentaire de Physiologie, 2nd ed., vol. 2, Paris, 1833, p. 387.

76 J. Paget, 'Report on microscopic anatomy in Britain', Med. Rev., 1842. 


\section{A. E. Best}

consisting of 'straw coloured fibres' coiled obliquely round the circumference. ${ }^{76} \mathrm{~F}$. Gerber, whose work was published in an English translation in 1842 under the title, Elements of the General and Minute Anatomy of Man and Mammalia, and who gave in some detail the kind of instruments and the microscopic methods which he employed, described the middle coats of blood-vessels as being made up of fibres of fine organic or contractile tissue running in 'spirals' and which under 'appropriate stimuli' would reduce both the diameter and the length of the vessel. ${ }^{27}$ And this, of course, was before the work of Kölliker.

With the growing awareness that the fibrous tissue within the middle coat of bloodvessels was muscular, the problem of arterial contraction became assimilated to that of muscular contraction. Indeed, for a period of over twenty five years before Lister's Edinburgh experiments, it would have been almost impossible for a medical student to approach the topic of blood-vessels without being aware of these wider implications. What he did not read in the pages of widely-circulated text-books, he would doubtless hear from the lips of those who wrote them. Béclard's excellent manual, Elements of General Anatomy, published in Edinburgh in 1830, included an account of the views of late eighteenth- and early nineteenth-century physiologists on arterial contractility and referred specifically to the work of Forsten-Verschuir, G. B. Bikker, H. Van den Bosch, C. S. Giulio and F. Rossi. After explaining that the phenomenon is more easily seen in small arteries, he concluded that such irritability . . . is more or less subject to the nervous influence'. ${ }^{78}$ Elsewhere, referring back to the theory of Sömmerring that the sympathetic is the nerve of the arteries, he conceded that arteries receive many sympathetic twigs. ${ }^{79}$ This discussion is considerably elaborated in Jones Quain's Elements of Anatomy, which was mentioned above. Confirming that nerves 'ramify' upon the structure of the arteries, the author distinguishes between vessels of the viscera which receive sympathetic nerves, and others, which receive cerebro-spinal nerves. ${ }^{80}$ In certain respects (the account continued) arteries show 'several points of resemblance to the muscular structure', their contractility, a 'vital property', being different from that 'resiliency' which characterizes merely elastic matter. The author quotes the research of Allen Thomson, who produced complete vascular constriction by irritating with a needle-point, or with a solution of alkali, the small arteries in the hind webs of a frog, and the researches of C. Giulio, F. Rossi, and E. Home, who obtained the same effects by irritating a neighbouring nerve in the foot. Other evidence is given in support of the theory of a 'vital property' of arteries. For instance, in lower animals, where there appeared to be no heart, the vessels were observed to propel the fluid; in reptiles, there were indications that arteries were still pushing the blood along, even after the removal of the heart; and in warm-blooded animals, there would still seem to be circulation in the capillaries after the ligation of the aorta. Hence, the same author concluded: the "heart and arteries may be considered as associated in a . . . special function, each being endued with an independent power, one acting by direct propulsion, the

76 Jones Quain, Elements of Anatomy, 4th ed., London, 1837, p. 79f.

7 F. Gerber, op. cit., text and appendix, p. 296.

$78 \mathrm{M}$. Beclard, Elements of General Anatomy (trans.), Edinburgh, 1830, p. 198.

10 Ibid., p. 362.

¿ones Quain, loc. cit. 


\section{Reflections on Joseph Lister's Edinburgh Experiments on Vaso-motor Control}

others assisting by their vital force and elasticity'.81 Grainger's anatomical text-book, which appeared in 1829, was raising the same queries and giving nearly the same answers as those found in the 1837 edition of Jones Quain's Elements of Anatomy, or in Allen Thomson's 1848 edition of Outlines of Physiology. Grainger, who had apparently experimented in this field, ascribed an active contractile power to the arteries, which assisted in circulation. 'This force', he wrote, 'which has great resemblance to muscular contractility, appears to have the same relation to the nervous system as the power of the heart; being under ordinary circumstances independent of the nervous power, but yet susceptible of being influenced by agents applied to the brain or spinal cord' ${ }^{82}$ True, the nerves supplying the arteries were part of what was anatomically classified as the sympathetic system, but this received 'communicating branches' from every part of the spinal cord. ${ }^{83}$

Meanwhile, J. Müller was arguing mainly against the muscularity of arterial walls, which, he claimed, unlike true muscular tissue, were not responsive to electrical or mechanical stimulus, ${ }^{84}$ even though there were explainable contractions through direct chemical action. He wrote: 'Dr. Hastings [On Inflammation of Mucous Membranes, London, 1820] was in error when he imagined the contractions produced by chemical agents to be muscular in their nature; and also when he failed to recognise that the true cause of the contraction of the arteries, which follows their dilatation or pulse, is the elasticity of the coats ...' (italics added). Writing in the same work on the fibrous appearance of the middle coat of the arteries, he maintained that the 'flat fibres and bundles of fibres, which surround the vessel in a circular direction, are not muscular in their nature'. It is these fibres, he continued, to which the 'arteries owe their great elasticity, or the property of contracting to their original diameter after being distended', this 'elasticity being a physical property', which is 'preserved for a considerable period after death'. ${ }^{85}$ In spite of inconsistencies in the account, his view was evidently that contractions and distensions of arteries were due solely to the opposing tensions of an elastic membrane and blood-pressure, and the pulsations in the dorsal vessels of insects, or-after the removal of the heart-in the 'artery passing over the great transverse process of the third vertebra' of a frog, were a mistaken view of insect-hearts in the one case, or of the motions caused by 'lymphatic' hearts in the other. ${ }^{86}$

Those like W. B. Carpenter, however, who favoured Hallerian doctrines, maintained that the walls of arteries were responsive to direct stimulation, and that this phenomenon was merely another example of muscular 'irritability'. Thus Carpenter wrote:87 'It is of course in the smaller arteries, that the evidence of this contractility should be sought; and this may be readily obtained by observing the effects of various stimuli, mechanical, chemical, or electrical, upon the vessels of a transparent membrane, such as the bat's wing or the frog's foot'. He described the simple experiment

'1 Jones Quain, op. cit., p. 84.

is R. D. Grainger, Elements of General Anatomy, London, 1829, p. 279.

Loc. cit.

थ J. Müller, Elements of Physiology, trans. by Baly, vol. 1, London, 1838, p. $205 f$.

ss Op. cit., p. 199

86 Op. cit., p. 203 W. Carpenter, Principles of Human Physiology, London, 1853, p. 488. 


\section{A. E. Best}

of stroking the membrane gently with the point of a needle and observing the contractions and subsequent dilatations of conveniently-seen arterioles. Also, as additional evidence of direct response to mechanical stimulation, he quoted the fact observed by J. Paget that, whilst being cut through in surgery, the small blood vessels would immediately contract and close so as temporarily to cease bleeding. ${ }^{88}$

After reflecting on all the many and conflicting views that had been expressed on the topic of arterial contractility, Carpenter achieved in his own account what was probably the most effective synthesis to be presented up to the beginning of the 1850 s. He claimed, as we have said, that the wall of the artery was self-contractile tissue, and this property he located in the yellow fibres, which had been observed by several microscopic physiologists to compose the tunica media. Such contractility, he held, which was obviously different from merely physical elasticity, probably assisted the heart in maintaining the flow of blood, and in controlling the volume of circulating blood. ${ }^{89}$ However, he recognized that there was also an overriding control of the diameter of the arteries, and in accordance with the prevailing view he ascribed this to the sympathetic nerve. ${ }^{20}$

Carpenter gave the conventional description of the sympathetic system in the trunk as consisting of two chains of vertically-connected ganglia. The off-shoots from these ganglia, he stated, were distributed not to the skin and muscles, like the nerve-fibres which extended from the cerebro-spinal system, but to the organs of digestion, secretion, to the heart, to the lungs and 'particularly to the walls of the blood-vessels'. ${ }^{91}$ It had, of course, been long suspected that the innervation of these parts was the special function of the sympathetic nerve. But Carpenter went further. From the fact that contractions could be produced in tissues supplied with sympathetic nerves, after the death of the animal, not only by the stimulation of the sympathetic trunk, but by the stimulation of those (higher) spinal roots with which the sympathetic trunks appeared to communicate by means of white fibres, he was led to the same conclusion as his contemporary physiologists, Budge, Waller and others, namely that the 'motor-power' of the sympathetic system is 'dependent on the cerebro-spinal system'. In view of the well-established fact that sympathetic nerves were 'copiously' distributed in the muscular tissue which partly formed the lining of the blood-vessels, there seemed to be a sufficient reason, Carpenter claimed, for 'attributing to the sympathetic system . . . a control over this [contractile] power', even though such control by the sympathetic system must be derived ultimately from its liaison with the spinal cord. ${ }^{92}$

If such theoretical explanations were given in physiological lectures in Lister's days as a medical student in London-and Carpenter was indeed a medical teacher as well as an examiner in physiology and comparative anatomy to the University of London at that time, and if, as is highly likely, Lister had been primed with this discussion, then the Edinburgh experiments may be interpreted as a reaction to the

s8 J. Paget, 'Lectures on inflammation', Med. Gaz., June, 1850.

0 W. B. Carpenter, A Manual of Physiology including Physiological Anatomy, London, 1854, p. $365 f$.

1 Loc. cit.

12 Op. cit., p. 602.

๑2 Op. cit., p. 366. 


\section{Reflections on Joseph Lister's Edinburgh Experiments on Vaso-motor Control}

theory of vitalism. As we have seen, Lister set out to show that those motor effects in the smaller arteries, which could be conveniently seen in the translucent webs of a frog, were ultimately controlled by the central nervous system. In reacting to midnineteenth-century vitalism, Lister was following the lead of such physiologists as Budge, Waller and Bernard, whose research on vaso-motor phenomena was based primarily on the rational assumption that such effects must be traced in the last resort to the central nervous system. This, of course, was opposed to the more occult theory that the self-contractility of muscular tissue was, in the words of the subscriber to the 1859 edition of the Encyclopaedia Britannica, one of the 'ultimate' and irreducible facts of physiology.

Yet, probably to his disappointment, Lister's experimental observations tended to show that vaso-motor control, as seen in the 'tone' of the smaller arteries, was partly independent of nervous control. We speak of his disappointment, because having decided prematurely that arterial constriction was wholly under the control of the central nervous system, he had no satisfactory explanation to offer, when he observed that the vessels would contract tonically even after their apparently complete denervation. Perhaps, until the limb had been severed, the denervation was not as complete as he had supposed. Nevertheless, as we have seen, he judged it to be complete. What is surprising, therefore, is that he did not fall back on the model of 'irritability' of the muscular fibres of the middle coat, whatever its vitalistic associations, especially as there was evidence that plain muscular fibres were responsive to chemical stimuli. Lister was aware from other research which he had carried out, that there were certain motor-effects-for instance, the concentration of pigment-granules within the chromatophores of Rana temporaria-which, judged by his most painstaking microscopy, seemed to have no apparent connection with the nervous system. ${ }^{93}$

Also, he observed within the same areas of the skin a certain concomitancy between the restriction of the smaller arteries, and the concentration of pigment-granules in the chromatophorous cells. Furthermore, he had shown that chromatophores would respond directly to such substances as curare applied to the skin. But he never appeared to have entertained the possibility that the constriction of the walls of arterioles, as well as the concentration of pigment-granules within chromatophores, might be due to the stimulus of agents which had been released into the bloodstream by some more remote mechanism. In other words, he remained committed to the view that there could be no muscular contraction without innervation, and he accounted for the spasmodic contractions of the arteries after the complete detachment of the leg, by assuming the existence of a local, independent system of ganglia. ${ }^{94}$

Lister was so obviously intent on explaining arterial contractions as a motorfunction of the central nervous system, that he had no wish to bring the sympathetic nerve into his account. This is remarkable, not only because it had long been suspected that the nerves which supplied the arterial walls came from the sympathetic chain, but because it had been shown on the one hand, by dissection, that the sympathetic

"2 A. E. Best, 'Lister's microscopic research on chromatophores', Proc. R. Micros. Soc., 1967, $2,425$.

o There is a hint of conversion to the doctrine of inherent vitality, though in very doubtful terms, in a short notice on a surgical case written by Lister around May 1858. See 'A case . . . illustrating the persistent vitality of the tissues', Edin. med. J., 1858, 4, 119. 


\section{A. E. Best}

chain received white rami-communicantes from the spinal cord, and on the other hand that stimulation of the sympathetic trunk (and of its ganglia) would produce motor effects in the abdominal viscera. ${ }^{95}$ An extension of such methods as those employed by Valentin to the problem of the part played by the sympathetic system in vaso-motor control, would surely have been well within the experimental resources of Lister. He might, for instance, have observed the effects on the arterioles of the web by systematically snipping out the ganglia of the sympathetic chain, or of sectioning the sympathetic chain at different levels, or of sectioning the white rami where they occurred between the ventral roots and the sympathetic ganglia. Of course, it is futile to speculate on what he might have done. Nevertheless, it is relevant to consider where he failed to exploit what was so evident in his findings. As far as mid-nineteenth-century means would allow, he established that vaso-constrictor fibres originated in 'centres' within the cerebro-spinal system, and in doing this, he was probably the first to use micro-metric methods so exhaustively. His failure was in not grasping the most obvious implications of his results, namely the light which they could have shed on the relationship between the central nervous and the sympathetic systems.

os G. C. Valentin, De functionibus nervorum cerebralium et nervi sympathici, Berne, 1839, vol. 2, chap. 2. 